\title{
The Effect of Blended Learning and Digital Literacy model on understanding the Sutta Pițaka
}

\author{
Mujiyanto ${ }^{*}$, Suherman2 \\ ${ }^{1}$ Buddhist Education, Smaratungga Buddhist College, Boyolali, Indonesia
}

ABSTRACT

Understanding of Sutta Pițaka is extremely important for master's degree of Buddhist Education students. The purpose of this study is to explore how the influence of blended learning and digital literacy learning models on the understanding of Sutta Pitaka for master's degree of Buddhist Education students. Employing a quantitative approach with ex-post facto research methods, the sample in this study is all master's degree of Buddhist Education students (S2) year of 2019 with a total of 36 students. The instrument used in this study is a questionnaire with a Linkert scale. The results of the validity and reliability test stated that the instrument was valid and reliable. Hypotheses were tested using regression analysis. The results showed that the blended learning model had a positive and significant effect on understanding the Sutta Pitaka with an effective contribution of $32.88 \%$. Digital literacy has a positive and significant effect on understanding the Sutta Pițaka with an effective contribution of $45.51 \%$. The blended learning and digital literacy learning models have a positive effect of $78.4 \%$ on the understanding of the Sutta Pitaka. Based on the result, it can be said that blended learning and digital literacy give a good impact on students to gain sufficient understanding of the Sutta Pitaka. The research contributes to the growth of science and technology in the education field, particularly maximizing the skill and knowledge using blended learning and digital literacy model on understanding the Sutta Pitaka.

\section{ARTICLE INFO}

\section{Keywords:}

Blended Learning; Digital

Literacy; and Sutta Pițaka

\section{Article History:}

Received: June $20^{\text {th }}, 2021$

Revised: June 25th 2021

Accepted: June $26^{\text {th }}, 2021$

Published: June 28 $8^{\text {th }}, 2021$

How to Cite in APA Style:

Mujiyanto \& Suherman.

(2021). The Effect of Blended Learning and Digital Literacy model on understanding the Sutta Pițaka. Smaratungga: Journal of Education and Buddhist Studies, 1(1), 55-66.

\section{Introduction}

In today's era of disruption, the development of science and technology is increasingly sophisticated and advanced. The impact of the development of the era of disruption has changed the order of people's lives in various sectors of life, including the education sector. Education, which is actually a conscious and planned effort in preparing a whole person, has begun to turn into a commodity that must struggle to exist and be able to adapt to the development of science and technology. Educational innovation can be seen from the implementation of online-based learning models, especially in higher education, such as the term elearning, online learning, web-based training, online courses, web-based education and so on.

Blended learning which is widely adopted by across higher education is a

\footnotetext{
*Corresponding author: mujiyanto1220@gmail.com

Published by Center of Research and Publication of Smaratungga Buddhist College

This is an open access article under the CC BY-NC 4.0

(https://creativecommons.org/licenses/by-nc/4.0/)
} 
type of learning that combines the advantages of learning through three main learning sources, namely face-to-face, online, and offline learning. Blended learning is a new concept in learning where delivery the teaching can be done in class and online (Husamah, 2014). This blended learning-based learning model with some scholars refer to it as the "new traditional model" or the "new normal" in course delivery (Norberg et al, 2011) is efficient for distance education. Blended learning is not limited to the time, place, and way to learn as it is wished by students (Tang and Chaw, 2015).

The concept of blended learning is mixing conventional learning models with online learning. Blended learning is a form of mixed learning that combines traditional learning with the current available technology (Samarescu, 2016). Blended Learning is a learning approach that combines learning delivery strategies using face-to-face activities, computer-based learning (offline), and online computers (Internet and Mobile Learning) (Dwiyogo, 2018).

There are four types of classification of e-learning, namely: (a) e-learning without attendence and without communication; (b) e-learning without attendance but with communication; (c) e-learning that is combined with occasional attendance; and (d) e-learning is used as a tool in classroom teaching (Dwigiyo, 2018). In America, the blended learning model that has been implemented in primary and secondary schools are classified into four categories, namely: (a) rotation model; (b) flex model; (c) self-blend model; and (d) enriched virtual model (Staker and Horn, M. B., 2012). These models refer to a complete school learning experience that allows students in a subject to divide their time between attending the study in schools and independent study in separate places with the delivery of contents and materials online.

The results of a survey conducted by Central Connecticut State University in 2016, it showed that Indonesia was ranked 60th out of 61 countries (https://webcapp.ccsu.edu/?news=1767\&data) with the Program for International Student Assessment (PISA) reading score, and Indonesia was ranked 64th out of 72 countries score INAP still showed of deficient category. The reading index of the Indonesian people is only 0.00 , meaning that the reading index of the Indonesian people has not had any achievements. Moreover, data showed by UNESCO mentioned that only 1 from 1000 people of Indonesia has good reading habit (in Hannah et al, 2020). It should pay more attention because reading skill is fundamental requirement to master knowldge, skill and charakter building on the part of students (Arafik, 2017). Therefore, it is important to implement digital literacy in the world of education, from basic education to higher education.

It should raise special concern because reading skill is basic requirement to master knowldge, skill and charakter building on the part of students. Low reading habit of Indonesian people is also caused by lack of books. It is apparent from what is stated by resource person in Mata Najwa program broadcasted on Wednesday of June 7th, 2017 with "Spreading reading virus".

However, the blended learning can be conducted successfully if supported by the help of digital technology. It has been posited that to make effective use of technology for learning, one needs to have a certain level of digital literacy. Digital literacy for learning is not just knowing how to operate the technology, but it requires the right information management and critical thinking skills, as well as 
proper online behaviours (Tang and Chaw, 2015). The concept of digital literacy, in line with the terminology developed by UNESCO in year 2011, which refers to and cannot be separated from literacy activities, such as reading and writing, as well as mathematics related to education. Digital literacy is not merely life skills related to mastering digital sources and devices (Pattah, 2014), but it also required social skills, ability in learning, have attitudes, think critically, creatively, and inspire as digital competencies (Tim Penyusun, 2017). The higher education emphasize teaching for understanding and critical thinking rather than information imparting (Shao and Purpur, 2016).

There are eight essential elements to develop digital literacy, namely as follows: (a) cultural, namely understanding the various contexts of users of the digital world; (b) cognitive, namely the power of thinking in assessing contents; (c) constructive, namely the creation of something that is expert and actual; (d) communicative, namely understanding the performance of networks and communications in the digital world; (e) responsible self-confidence; (f) creative, doing new things in new ways; (g) critical in addressing content; and (h) socially responsible (Belshaw, 2011).

On the other hands, the basic principles of digital literacy development that should be fulfilled according to the Ministry of Education and Culture of the Republic of Indonesia, are: (a) understanding; (b) interdependence; (c) social factors; and (d) curation (Ministry of Education and Culture of the Republic of Indonesia, 2017). Moreover, the literacy development emphasizes these six principles, as: (a) the predicable stage of the developmental stages of literacy of students; (b) balanced; (c) literacy programs are integrated with the curriculum; (d) reading and writing activities are carried out at any time; (e) literacy activities develop oral culture; and (f) literacy activities need to develop awareness of diversity (Beers et al, 2009).

The blended learning process and the application of digital literacy for master's degree of Buddhist Education students include scheduled face-to-face lectures, online classes, thesis proposal seminars, journal writing and study evaluations. Learning for master's degree of Buddhist Education study program through the blended learning model has used online learning applications such as video conference zoom.us, google classroom assignment application, Schoology, and Whatsapp as well as telegram. Through these various digital applications, the master's degree of Buddhist Education students are able to optimize digital literacy and if it is associated with lectures, then it will be much more possible to increase the quality of learning.

The concept of digital literacy, that each individual is expected to have the ability to understand and use information from various sources presented in digital form so as to have the ability think critically and able to express themselves and participate in the media, especially in the learning process. Therefore, the focus of this research is on relevancy blended learning and digital literacy for understanding the Sutta Pițka.

\section{Method}

This study uses a quantitative approach with ex-post facto research methods. The nature of the ex-post facto research is that there is no control over the variables. 
This research was carried out using descriptive inferential research procedures to examine the effect of independent variables on the dependent variable. The population in this study were all 36 students of the master degree of Buddhist Education STIAB Smaratungga. The sample in this study is the entire population.

The method used to collect data in this study is the method of observation, documentation, and questionnaires. Observation and documentation methods were carried out to obtain qualitative and quantitative data related to the description and characteristics of the research object. Questionnaire method was used to obtain quantitative data related to respondents' responses to research variables. The type of questionnaire used in collecting data in this research is a structured questionnaire consisting of questions and statements with a certain number of answers as options, the respondent just chooses the answer that best suits his/her stance.

Data analysis is intended to test the truth of the hypothesis. The data analysis technique used in this research is regression analysis, both simple regression and multiple regression. Before the data analysis was carried out, a description of the research data was carried out which consisted of two independent variables and one dependent variable in the form of frequency distribution tables and diagrams. The next step is to carry out a data analysis requirements test which consists of a normality test, a linearity test, and a multicollinearity test. The hypothesis tested in this study is the influence of the independent variables $\left(\mathrm{X}_{1}\right.$ and $\left.\mathrm{X}_{2}\right)$ on the dependent variable $(\mathrm{Y})$ either partially or simultaneously. To find out whether the independent variable $X$ has an influence on the dependent variable $Y$, it is done by calculating the value of the statistical $F$ test. The influence of the independent variables $\left(\mathrm{X}_{1}\right.$ and $\left.\mathrm{X}_{2}\right)$ together on the dependent variable $\mathrm{Y}$ is done by calculating the value of the coefficient of determination (R2). While the magnitude of the effect of each independent variable on the dependent variable is determined based on the results of the statistic t test (Purwanto, 2007: 193-194). The calculation of the value of the statistic F test and the value of the $t$ statistic in this study used the SPSS Statistics 21 program.

\section{Findings}

\section{Variable descriptive analysis}

\section{Analysis descriptive blended learning model $\left(\mathrm{X}_{1}\right)$}

Respondents' responses to the blended learning model variable $\left(\mathrm{X}_{1}\right)$ showed an average score of 3.79 with a good category. Of the 36 respondents, 9 respondents said it was very good, 24 respondents said it was good, and 3 respondents said it was quite good. There are no bad and very bad responses to the blended learning model variables. Respondents' responses to the face-to-face (conventional) subvariable showed an average score of 3.90 in the good category, the computerbased learning activity sub-variable (offline) was 3.62 in the good category, and the computer-based learning activity sub-variable (online ) is 3.77 with good category

\section{Digital literacy descriptive analysis $\left(X_{2}\right)$}

Respondents' responses to digital literacy $\left(\mathrm{X}_{2}\right)$ showed the average score of 36 respondents' responses to 35 digital literacy variable statement items was 3.67 
with good categories. Of the 36 respondents, 8 respondents said it was very good, 18 respondents said it was good, and 10 respondents said it was quite good. There are no bad and very bad responses to digital literacy variables. Respondents' responses to the ability to find subvariable showed an average score of 3.86 with good category, sub-variable ability to evaluate was 3.67 with good category, subvariable of ability to utilize was 3.22 with good category, sub-variable ability to share was equal to 3,85 with good category, and the sub-variable of the ability to create content is 3,71 with good category.

\section{Descriptive Comprehension Analysis of the Sutta Pițaka (Y)}

Respondents' responses to the variable understanding of the Sutta Pitaka (Y) showed the average score of 36 respondents' responses to the 35 statement items of the understanding Sutta Pitaka's variable was 3.83 with good categories. Of the 36 respondents, 10 respondents said it was very good, 20 respondents said it was good, and 6 respondents said it was quite good. There are no bad and very bad responses to the variable understanding of the Sutta Pitaka. Respondents' responses to the sub-variable translating the concept were 3.93 in the good category, the sub-variable for interpreting the concept was 3.94 in the good category, the sub-variable for concluding the concept was 3.64 in the good category, and the sub-variable for extrapolating the concept was 3.81 in the category good.

\section{Test requirements}

The results of the normality test show that the data on the blended learning model variable $\left(\mathrm{X}_{1}\right)$ has a significance number of 0.026 . Meanwhile, the data on the digital literacy variable $\left(\mathrm{X}_{2}\right)$ and the understanding of the Sutta Pitaka (Y) have a significance number of 0.200 . This figure shows that the data on the variable digital literacy $\left(\mathrm{X}_{2}\right)$ and understanding of the Sutta Pitaka (Y) are normally distributed (Sig> 0.05). The results of the linearity test showed that all variables had significance values of less than 0.05 so that the research variables were linear. The results of the multicollinearity test show that the VIF value in the blended learning $\left(\mathrm{X}_{1}\right)$ and digital literacy $\left(\mathrm{X}_{2}\right)$ learning model variables is 3.752 so it can be concluded that there is no multicollinearity in the data of this study.

\section{Analysis regression}

The correlation value $(\mathrm{R})$ between the variables of the blended learning model $\left(\mathrm{X}_{1}\right)$ on the understanding of the Sutta Pitaka (Y) is 0.843. This value can be interpreted that the relationship between the two variables being tested is in the very strong category. The coefficient of determination value obtained is $71 \%$ so that it can be interpreted that the blended learning model variable $\left(\mathrm{X}_{1}\right)$ has an influence contribution of $71 \%$ on the variable understanding of the Sutta Pitaka (Y). The results of the simple regression coefficient calculation show that the coefficient value of the constant is -4.359 and the coefficient value of the independent variable $\left(\mathrm{X}_{1}\right)$ is 1.043. So that the regression equation $\mathrm{Y}=-4.359+1.043 \mathrm{X}$ is obtained.

The correlation value $(\mathrm{R})$ between digital literacy variables $\left(\mathrm{X}_{2}\right)$ on the understanding of the Sutta Pitaka (Y) is 0.862 . This value can be interpreted that 
the relationship between the two variables being tested is in the very strong category. The value of $\mathrm{R}$ Square or the coefficient of determination shows how good the regression model formed by the interaction of the independent variable and the dependent variable is. The coefficient of determination value obtained is $74.4 \%$ so it can be interpreted that the digital literacy variable $\left(\mathrm{X}_{2}\right)$ has an influence contribution of $74 \%$ on the variable understanding of the Sutta Pitaka (Y). The results of simple regression analysis show the coefficient value of the constant is 21,958 and the coefficient value of the independent variable $\left(\mathrm{X}_{1}\right)$ is 0,877 . So that the regression equation $\mathrm{Y}=21.958+0.877 \mathrm{X}$ is obtained.

The correlation value $(\mathrm{R})$ between blended learning model variables $\left(\mathrm{X}_{1}\right)$ and digital literacy $\left(\mathrm{X}_{2}\right)$ on understanding the Sutta Pitaka $(\mathrm{Y})$ is 0.886 . This value can be interpreted that the relationship of the three variables tested is in the very strong category. The coefficient of determination is 0.784 so it can be interpreted that the blended learning $\left(\mathrm{X}_{1}\right)$ and digital literacy $\left(\mathrm{X}_{2}\right)$ learning models contribute $78.4 \%$ influence on the understanding of the Sutta Pitaka (Y). The results of multiple regression analysis show that the coefficient of the constant is 0.996 , the regression coefficient of the $\mathrm{X} 1$ variable is 0.483 , and the regression coefficient of the $\mathrm{X} 2$ variable is 0.537 . So that the regression equation $\mathrm{Y}=0.483 \mathrm{X} 1+0.537 \mathrm{X} 2$ is obtained. 0.996.

\section{Analysis of effective contribution and relative contribution}

The calculation of SE and SR of each variable based on the data in table 4.52 shows that the blended learning model variable $\left(\mathrm{X}_{1}\right)$ has an effective contribution (SE) of $32.88 \%$ and a relative contribution of $41.94 \%$, while the digital literacy variable has an effective contribution. (SE) of $45.51 \%$ and relative contribution (SR) of $58.05 \%$. The results of these calculations indicate that the digital literacy variable contributes a more dominant influence on the variable understanding of the Sutta Pitaka compared to the blended learning model variable.

\section{Analysis of relationship per subvariable}

The correlation coefficient of the $\mathrm{X}_{1}$ variable to the $\mathrm{Y} 1$ sub-variable is 0.791 . The correlation coefficient of the X1.1 sub-variable to Y2 is the largest, which is 0.833 . The correlation coefficient of the variable $\mathrm{X}_{1}$ to the sub-variable $\mathrm{Y} 2$ is 0.782 . The correlation coefficient of the $\mathrm{X}_{1}$ variable with the largest sub-variable $\mathrm{Y} 3$ is 0.850 . The sub-variable X1.3 has a correlation coefficient to Y3 of 0.835 . The sub-variable $\mathrm{X} 1.1$ has the greatest correlation coefficient to $\mathrm{Y} 4$, which is 0.770 . The correlation coefficient of the $\mathrm{X}_{1}$ variable with the largest sub-variable $\mathrm{Y} 4$ is 0.754 . The subvariable X1.1 as a whole has the strongest correlation to $\mathrm{Y}$, which is 0.858 . This means that face-to-face (conventional) activities (X1.1) most influence the understanding of the Sutta Pitaka (Y). Correlation analysis of variable $\mathrm{X}_{1}$ to subvariable Y1. Y2, Y3, and Y4 shows that the blended learing-based model ( $\left.\mathrm{X}_{1}\right)$ contributed the most to the sub-variable of concluding concept (Y3).

The correlation coefficient of $\mathrm{X}_{2}$ to $\mathrm{Y} 1$ is 0.828 . The greatest correlation coefficient of $\mathrm{X}_{2}$ to $\mathrm{Y} 2$ is 0.843 . The sub-variable $\mathrm{X} 2.4$ has a correlation coefficient to $\mathrm{Y} 1$ of 0.837 . The greatest correlation coefficient of $\mathrm{X} 2$ to $\mathrm{Y} 3$ is 0.813 . The subvariable X2.2 has a correlation coefficient to Y1 of 0.802 . The greatest correlation 
coefficient of $\mathrm{X}_{2}$ against $\mathrm{Y} 4$ is 0.761 . The sub-variable $\mathrm{X} 2.4$ has a correlation coefficient of 0.748 to Y4. The sub-variable X2.2 as a whole has the strongest correlation to $\mathrm{Y}$, which is 0.925 . That is, the ability to evaluate (X2.2) has the most influence on understanding the Sutta Pitaka (Y). Correlation analysis of variable $\mathrm{X}_{2}$ to sub-variable $\mathrm{Y} 1$. $\mathrm{Y} 2, \mathrm{Y} 3$, and $\mathrm{Y} 4$ show that digital literacy $\left(\mathrm{X}_{2}\right)$ contributes the most to the sub-variable interpreting the concept (Y2).

\section{Discussion}

\section{The effect of the Blended Learning model on understanding the Sutta Pițaka}

The results of the first hypothesis test indicate that the regression direction coefficient of the blended learning model variable $\left(\mathrm{B}_{1}\right)$ is 1.043 , so it can be stated that the blended learning model variable has a positive effect on understanding the Sutta Pitaka. The significance test of multiple linear regression coefficients for blended learning model variables $\left(\mathrm{B}_{1}\right)$ shows tcount $(9.120)>$ ttable (1.688), Significance $(0.000)<0.05$ with an effective contribution (SE) of $32.88 \%$ and a relative contribution of $41,94 \%$.

The results of data analysis show that the better the blended learning learning model, the stronger the understanding of the Sutta Pitaka possessed by the 2019 master's degree students. The blended learning model that has been applied in lectures in the Buddhist religious education study program (S2), especially for postgraduate students academic year of 2019/2020 went well by meeting the following criteria:

\section{Face-to-face activities (conventional)}

Learning through face-to-face (conventional) activities has been carried out well. The blended learning model can be implemented through face-to-face (conventional) activities on a scheduled basis. The interaction between lecturers and students during face-to-face lectures shows that face-to-face (conventional) lectures run effectively. Face-to-face activities (conventional). The blended learning model includes face-to-face lectures, online and offline learning. The Thematic Sutta Lectures have been implemented well through face-to-face activities (conventional) with the delivery of teaching by lecturers directly to students. This statement is evidenced by the responses of respondents to face-toface activities (conventional) have an average of 3.90 with good categories.

\section{Computer-based learning (offline)}

The blended learning model has also successfully implemented learning through offline-based computer learning. Offline-based learning which includes learning assignments through Google Classroom, independent learning through learning resource books, assignment orders via WhatsApp groups, sending learning resources in the form of e-books, journals with assignments to review and analyze. Offline computer-based learning has been running well and smoothly. This statement is evidenced by the respondents' responses to offline computerbased learning have an average of 3.62 with good categories. 


\section{Computer-based learning (online)}

In addition to the application of conventional learning and offline-based learning, the blended learning model has successfully implemented learning through online-based computer learning. Online-based learning includes lectures directly through the zoom.us application, interactive-based online discussions, and online assignments (on the network). The use of computers and other electronic devices (hand phones) is the main facility for students to take online-based lectures via the zoom.us application. Computer-based learning (online) as a forum for direct interaction for lecturers and students during the process of delivering teaching. This computer-based learning (online) specifically for the thematic sutta courses that convey the Sutta Pitaka has been carried out well.

\section{Effect of Digital Literacy on understanding the Sutta Pitaka}

The results of the second hypothesis test show that the regression direction coefficient of the digital literacy variable $\left(\mathrm{B}_{2}\right)$ is 0.877 so it can be stated that the digital literacy variable has a positive effect on understanding the Sutta Pitaka. The significance test of multiple linear regression coefficients for the digital literacy variable $\left(\mathrm{B}_{2}\right)$ shows tcount $(9.930)>$ ttable $(1.688)$ and a significance value $(0.000)$ $<0.05$ with an effective contribution (SE) of $45.51 \%$ and a relative contribution (SR) of $58.05 \%$. The calculation results show that the digital literacy variable contributes a more dominant influence on the variable understanding of the Sutta Pitaka compared to the blended learning model variable.

The results of data analysis show that the better the students' digital literacy, the stronger the understanding of the Sutta Pitaka owned by the 2019 master's degree students. Digital literacy that has been applied in lectures in Buddhist education (S2) study programs through digital literacy, especially for postgraduate students academic year of 2019/2020 went well by meeting the following criteria:

\section{Ability find}

The ability to find focuses on students' digital literacy in all skills, such as the ability to read digital learning resources, search for references, and understand the technological devices used in lectures. Students' digital literacy towards skills in finding learning resources and digital references has been running. This statement is evidenced by the respondents' responses to the ability to find an average of 3.86 with a good category.

\section{Ability evaluate}

Students are able to evaluate the understanding of the Sutta Pitaka through the ability to evaluate in digital literacy. Students' digital literacy is well applied, marked by the ability of students to evaluate information from the internet, the ability to think critically and creatively towards information and statements sourced from the internet. The student's ability that can work well is evidenced by the respondents' responses to the ability to evaluate having an average of 3.67 with a good category. 
Ability take advantage of Students' digital literacy on the ability to utilize has been carried out well. The ability to use digital technology as a facility in finding sources for the Sutta Pitaka in learning. This statement is evidenced by the respondents' responses to the sub-variable of the ability to utilize an average of 3.22 with a good category.

\section{Ability share}

The ability to share has been applied by students. Student digital literacy is well tested with students' ability to share important information through digital media, share knowledge about the Sutta Pițaka, share knowledge about the use of digital applications in learning. This statement is evidenced by the respondents' responses to the sub-variable ability to share an average of 3.85 with a good category.

\section{Ability to create content}

The ability to create content focuses on students' digital literacy in all skills such as the ability to create educational content that supports lectures, especially the Sutta Pitaka, development of content such as blogs and websites in posting lecture articles related to the Sutta Pitaka. This statement is evidenced by the respondents' responses to the sub-variable of the ability to create content that has an average of 3.71 with a good category.

\section{The effect of Blended Learning and Digital Literacy learning models on understanding the Sutta Pițaka}

The results of the third hypothesis test show that the blended learning model variable and the digital literacy variable simultaneously affect the understanding of the Sutta Pitaka. The strengthening of the statement is indicated by the value of Fcount $(59,947)>$ Ftable $(3.28)$ and the significance value $(0.000)<0.05$. The coefficient of determination was obtained at 0.784 which means that the contribution of the influence given by the blended-based learning model and the digital literacy variable together to the variable understanding of the Sutta Pitaka is $78.4 \%$.

The strong understanding of the Sutta Pitaka for 2019 Masters students can be seen from the following elements:

\section{Translating concepts}

Master's degree students' understanding of the Sutta Pitaka on understanding is good. Students are able to translate the concept of understanding and the meaning of the Sutta Pitaka. These statements are evidenced by the respondents' responses to the sub-variables translating the concept have an average of 3.93 with good categories.

\section{Interpretting concept}

The understanding of the Sutta Pitaka for postgraduate students is shown in that the interpretation of the concept has gone well. Interpreting the concept of the 
procedure for studying the suttas and examining the problem or topic of discussion by getting settled through the sutta. These statements are evidenced by the respondents' responses to the sub-variables interpreting the concept has an average of 3.94 with good categories.

\section{Concluding concept}

The understanding of the Sutta Pitaka for postgraduate students is shown in the ability to conclude concepts that have gone well. Summarizing the concepts of the Sutta Pitaka and summarizes the main ideas that are important to study. These statements are evidenced by the respondents' responses to the sub-variables concluding the concept has an average of 3.64 with a good category.

\section{Extrapolating/taking into account concepts}

Masters students' understanding of the Sutta Pițaka has been implemented well. Understanding the the Sutta Pițaka with the ability to take into account concepts such as understanding the concept of the Sutta Pitaka which is divided into several sections/nikaya, and being able to take into account the criteria for the Sutta Pitaka in the difficult, medium, and easy categories. These statements are evidenced by the respondents' responses to the sub-variables extrapolating/taking into account the concept has an average of 3.81 with a good category.

The blended learning model $\left(\mathrm{X}_{1}\right)$ and digital literacy $\left(\mathrm{X}_{2}\right)$ contributed $78.4 \%$ influence on the understanding of the Sutta Pitaka (Y), so the remaining 21.6\% was influenced by other variables not examined in this study. These variables can be in the form of teaching methods of lecturers, IQ, educational background of S1 and social environment.

\section{Conclusion}

The Buddhist Education Study Program (S2) STIAB Smaratungga is located in the Gladagsari sub-district, Boyolali Regency, Central Java. S2 STIAB Smaratungga has implemented a blended learning learning model, namely learning that combines face-to-face learning, offline and online-based learning since 2017. Students have completed many courses through the blended learning model, one of which is Thematic Sutta courses, namely courses that discuss about basics of the Sutta Pitaka, learn about the study of the suttas and quote the suttas.

The understanding of the Sutta Pițaka can be formed through the application of the blended learning model. The main characteristic of the blended learning model is that learning can combine face-to-face learning (face to blended learning) with computer-based learning. Digital literacy skills that have been formed in the lecture process can strengthen the understanding of the Sutta Pitaka for postgraduate students because it contains characteristics in efforts to integrate the ability to find, evaluate, utilize, share and create content using technology and the internet. to the growth of science and technology in the education field, particularly maximizing the skill and knowledge using blended learning and digital literacy model on understanding the Sutta Pițaka. 


\section{References}

Arafik, M. (2017). The implementation of children literature instruction in elementary school. Advances in Economics, Business and Management Research, 45, 277-281. doi: 10.2991/coema-17.2017.48.

Belshaw, D. A. J. (2011). What is 'digital literacy'? Thesis. United Kingdom: Durham University. Retrieved from: https://clalliance.org/wpcontent/uploads/files/doug-belshaw-edd-thesis-final.pdf.

Hannah, D., Lisniyanti, K., \& Yulianto, S. W. (2020). Investigating students' reading interest on English reading materials through their reading habits during a pandemic. English Language Teaching in Focus, 3(2), 14-23. doi: 10.35706/eltinfc.v3i2.4585.

Dwiyogo, W. D. (2018). Pembelajaran Berbasis Blended Learning. Depok: Rajawali Pers

Emzir. (2019). Metodologi Penelitian Pendidikan Kuantitatif \& Kualitatif. Depok: PT Rajagrafindo Persada.

Hartati, T. (2016). Multimedia in literacy developmentat remote elementary schools in West Java. Edutech: Journal Educational Technology, 15(3), 301-310. doi: 10.17509/edutech.v15i3.4873.

Hasan, S. H. S. (2017). Patrap Triloka Ethno-Pedagogy with Research-Based Learning Settings to Develop Capability of Pre-Service Science Teachers: Literature Review. Proceedings of the 1st International Conference on Matematichs, Science, and Education (ICoMSE 2017) organized by Faculty of Mathematics and Natural Science State University of Malang, Indonesia, Atlantis Press. doi: 10.2991/icomse-17.2018.9.

Husamah. (2014). Pembelajaran Bauran (BLENDED LEARNING). Malang: Prestasi Pustaka.

Pattah, S. H. (2014). Literasi informasi: peningkatan kompetensi informasi dalam proses pembelajaran. Khazanah Al-Hikmah: Jurnal Ilmu Perpustakaan, Informasi, dan Kearsipan, 2(2), 117-128.

Samarescu, N. (2016). The Teacher's Role in Blended Learning and Teaching, The 12th International Scientific Conference eLearning and Software for Education Bucharest, April 21-22, 2016 10.12753/2066-026X-16-270.

Staker, H., \& Horn, M. B. (2021). Classifying K-12 Blended Learning. Cambridge: Innosight Institute.

Sugiyono. (2016). METODE PENELITIAN PENDIDIKAN Pendekatan Kuantitatif,

Tang, C. M., \& Chaw, L. Y. (2015). A Prerequisite for Effective Learning in a Blended Learning Environment? The Electronic Journal of e-Learning, 14(1), 54-65. Retrieved from www.ejel.org.

Tim Penyusun. (2017). Materi Pendukung Literasi Digital (Gerakan Literasi Nasional). Jakarta: Kementerian Pendidikan dan Kebudayaan.

Shao, X. and G. Purpur (2016). Effects of information literacy skills on student writing and course performance. The Journal of Academic Librarianship, 42(6), 670-678. doi: 10.1016/j.acalib.2016.08.006.

Norberg, A., Dziuban, C. D., \& Moskal, P. D. (2011). A time-based blended learning model. On the Horizon, 19(3), 207- 216. doi: 10.1108/10748121111163913. 
CCSU NEWS RELEASE. World's Most Literate Nations Ranked (Accessed on April 22nd 2020$)$. Available: https://webcapp.ccsu.edu/?news $=1767 \&$ data.

Beers, C.S., Beers, J. W., \& Smith, J. O. (2009). A Principal's Guide to Literacy Instruction. New York: Guilford Press. 